\section{No. 4811 January 13,1962}

director of health services from West Bengal, and a deputy municipal health officer from Kuala Lumpur, Malaya, while a deputy principal health officer from Burma took a course at the Royal Institute of Public Health and Hygiene, and the professor of dental surgery, Madras Medical College, a three-year course at the Institute of Basic Medical Sciences, Royal College of Surgeons. A physicist of the Cancer Research Institute, Madras, is doing postgraduate research at the Institute of Cancer Research, London.

A lecturer in veterinary science was provided for the University of Rangoon, equipment provided to improve the teaching facilities in the Departments of Chemistry and Engineering, University of Malaya in Kuala Lumpur, and lecturers in physics from the University of Dacca were trained in radiation physics and electron microscopy. Four professors and a workshop superintendent were provided for the College of Engineering and Technology, New Delhi; ten more professors and staff are to be provided, as well as training for members of the College staff. The professor of agricultural chemistry from the only agricultural institute of degree-level in Assam is receiving higher training at the University of Leeds. and advanced training was provided for a lecturer in mechanical engineering and an assistant professor of eivil engineering from the College of Engineering and Technology as well as for the professor of plant ecology of the University of the Panjab. The Institute of Education, University of London, runs an annual nine-months course for community officers which was attended by officers from Indonesia, Laos, Thailand and Vietnam. Traineos from Burma, Malaya, Indonesia, the Philippines and Thailand attended a course in public administration at the University of Manchester, while others from Burma, Ceylon, Malaya, India, the Philippines and Thailand attended a similar course at the London School of Economics. and a student from Ceylon a course at the Adminis. tration Staff College, Henley-on-Thames.

\title{
PHYCOLOGY IN BRITAIN
}

$\mathrm{T}$ HE recently published number of the British Phycological Bulletin (2, No. 2; 1961) provides ample evidence of a lively interest in the study of algae in Britain. Among the varied articles and reports, special mention should be made of the presidential address by Dr. Mary Parke. This address deals mainly with recent studies of the morphology, taxonomy and life-histories of the Chrysophyceae. It is clear from the account that the electron microscope has been of great value in taxonomic studies, by revealing details of the structure of the flagella, and of the structure of the scales in the scale-bearing forms. It is of interest that, even in the small number of forms so far examined, the scales show as wide a range of structure as that found in diatom frustules.

The recent work on the life-histories of representatives of the Chrysophyceae, especially by Dr. Parke herself, emphasizes the difficulties and exciting work awaiting the student of this algal class. Investigations in culture have demonstrated that, as in other groups of algae, genera originally thought to be distinct are actually different phases of the same life-history. Thus, in clonal eultures of three different coccolithophorids from the Plymouth collection, Syracosphaera carterae, Syracosphaera sp. (not yet named) and Pleurochrysis scherffelii, non-motile stages could be matched with forms of Chrysophyceas such as Chrysosphaera marina, Apistonema sp. and $A$. pyrenigerum from the Baltic, and $A$. carteri, Chrysonema litoralis, Thallochrysis litoralis, Chrysotila stipita and $C$. lamellosa from the chrysophycean zone on the chalk cliffs near Westgate. Equivalent stages are also found in the chrysophycean zone on the chalky sandstone cliffs of St. Andrews Bay, Scotland.

In addition to the coccolithophorid life-history with an Apistonema stage, Dr. Parke mentions two other types of life-history: the Coccolithus pelagicus type with a motile Crystallolithus phase and the Ochrosphaera neapolitana type, in which the motile cells are probably of different structure. These varied life-histories suggest that the present system of classifying the coccolithophorids on the morphology of their coccoliths will prove unsatisfactory in future and that eventually the classification may have to be based on the type of life-history. Thus, while one group of coccolithophorids may produce a benthic filamentous phase, perhaps growing best on a chalky substratum on the shore, another series, like Coccolithus pelagicus, may have a non-motile cyst stage from which the motile phase is again released when conditions are suitable. Yet another series may have its non-motile phase endophytic in the wall strata of another alga or symbiotic in some animal. It is also suggested that the external control of the phases is a possibility and may be of considerable importance from the fisheries angle, particularly in the production of food for the culture and rearing of shellfish larvæ. Dr. Parke concludes that time and patience will be required to relate the many described motile phases to their non-motile stages, as well as to clear up the many nomenclatural problems that will be involved.

Other articles deal with freshwater algae. Dr. J. H. Belcher and E. M. F. Swale describe some new and uncommon British Volvocales, including a species of a new genus Myochloris. In a contribution on Asterionella formosa Hass. var. acaroides Lemm., "at phycological enigma", Dr. J. W. G. Lund refers to the fact that although millions of cells of Asterionella have been observed, no one has yet seen auxospores in this genus. It was thought possible that var. acaroides might be the auxospore stage of $A$. formosa; but after examination of the available evidence it was concluded that the nature of this variety is still uncertain.

Returning to marine algae, Dr. Peter S. Dixon and Dr. Máirín de Valera, after a critical survey of evidence for the occurrence of Gelidium torulosum Kütz and $G$. melanoideum Schousb. ex Born. in Britain and Ireland, conclude that both species must be removed from the list of indigenous species, the existing records being based entirely on misidentifications. Dr. Joanna M. Kain contributes some useful records of sub-littoral algae, sampled by use of an aqualung, both from Alderney and from two regions off the west coast of Scotland.

Shorter accounts include the identification of Compsopogon coeruleus, from the Reddish Canal near Manchester; the occurrence of resting zygotes in the Chlorophyceae, with special reference to Carteria 
eugametos Mitra; the cytology of colonial Volvocales of south-eastern England; the unusual nature of the Dinophycean nucleus; the taxonomy of the Cryptophyceae; etc.

It is clear from this Bulletin that notwithstanding, or perhaps even as a result of, the recent emphasis on other aspects of phycology, work on the morpho$\log y$ and life-histories of the algae is being pursued with undiminished enthusiasm, and there can be no doubt that many stimulating problems in this field will still arouse the interest of future students of the algae.

A. Alilsopp

\section{THE INSTITUTE FOR SCIENTIFIC RESEARCH IN CENTRAL AFRICA}

$\mathrm{T}$ HE Institut pour la Recherche Scientifique en Afrique Centrale, founded in 1947, has five main centres in the Congo at Lwiro, Uvira, Astrida, Mabali and Elizabethville, and a number of sub-stations for field studies at Tshibati, Irangi, Uwinka (Ruanda), Bugesera and Mutara.

The twelfth annual report of the Institute *, written in French, is an impressive document of 253 pages illustrated by an appreciable number of photographs. It is divided into three sections dealing respectively with administration, including the report of the director-general, Prof. L. Van den Berghe, on the work of the Institute; review articles on the work of the Institute in certain broad fields, and abstracts of scientific papers written by the staff or those who have been in some way associated with it, and published in 1959.

The first part of the report gives, in addition to the report of the director-general, details of the constitution of the Institute, membership and activities of the various scientific committees connected with its work, and a financial statement. The report of the director-general includes not only details of the scientific activitios but also lists of visitors to the Institute during the course of the year and details of construction work carried out to extend and improve the various centres. One feels that much of the information given in the first forty pages of this administrative section of the report would be more appropriately situated in an appendix, thus leaving the report to deal primarily with the scientific work carried out. The same is true of the financial report, which is placed between the account of research activities and the section of the report devoted to review articles.

The range of scientific work covered by the Institute is vast. The report of the director-general gives details of work being carried out in the following fields: experimental zoology, including the capture, study and breeding of wild animals such as buffalo, chimpanzee and mountain gorilla; entomology;

* Institut pour la Recherche Scientifique en Afrique Centrale, Bruxelles. Douzleme Rapport Annuel, 1959. Pp. 253. (Bruxelles: parasitology, with particular reference to trypanosomiasis; human pathology including kwashiorkor, the effocts of vitamin $A$ and the role of different classes of lipids in human nutrition; anthropology, sociology and languages; archæology; hydrobiology and hydrology; plant geography, ecology and physiology; seismology and vulcanology. An observatory was under construction on Mount Tumbwe.

The four review articles which constitute the second part of the report are concerned with the part played by the Institute in the study of feeding and nutritional problems; hydrobiological research on Lake Tanganyika; physical sciences including seismology, vulcanology, solar-terrestrial phenomena and astrophysics; human sciences including cultural and physical anthropology, economics, African languages, prehistory and history. The list of scientific papers written by the staff and associates of the Institute during 1959, which is given in the final section of the report, covers the whole range of the work of the Institute. Abstrects of varying length are given for more than half the 103 papers listed.

Two main impressions are gained from reading these reviews and abstracts, and indeed from the report as a whole. First, that the Institute was attempting to cover too wide a scientific field for all aspects of its work to be really effective. Secondly, that it is not a pure research institute but is very much applied in its approach. The latter would seem to be very desirable in an institute working in an underdeveloped country where not only are the basic facts about the terrain and habits of the people largely unknown, but where also the applied work can only be carried out in the territory itself.

It is unfortunate that the Institute for Scientific Research in Central Africa, with the present diffieulties in the Congo, appears to have more or less ceased operations. It will be a considerable loss both to the Congo and to all underdeveloped territories if it does not continue, and it is to be hoped that the offorts being made at present by the authorities in the Congo to carry on the type of work started by the Institute will prove successful.

S. S. BAMptoN

\section{HORTICULTURAL RESEARCH}

$\mathrm{H}$ ORTICULTURE, either as an art or industry, is far more concerned with the behaviour of individual plants than its more extensive congener agriculture. It is an ideal setting for research on applied botany, and almost all agricultural problems must first be investigated on a horticultural scale. The garden itself poses urgent problems for scientific solution and they can be investigated effectively with either ecological directness or with the full majesty of basic science. There is, moreover, an immediate outlet for practical results, and the stringent, unsubsidized economics of the industry impose a rather more searching test of significance than even those of the mathematician. Horticulture in fact lies, in the research sense, at the cross-roads of many sciences-crop protection, plant physiology, genetics, and taxonomy - in addition to forestry and agriculture. It is rather surprising that there have 